Tarih Kültür ve Sanat Araştırmaları Dergisi

Revue des Recherches en Histoire Culture et Art

مجلة البحوث التاريخية و الثقافية والفنية
Vol. 6, No. 6, December 2017

Copyright (C) Karabuk University

http://kutaksam.karabuk.edu.tr

\title{
DOI: 10.7596/taksad.v6i6.1326
}

Citation: Abdullina, L. R., Nizamieva, L. R., \& Nazarova, G. I. (2017). Comments in the Internet Media as the Reflection of National Mentality Peculiarities. Journal of History Culture and Art Research, 6(6), 104-110. doi:http://dx.doi.org/10.7596/taksad.v6i6.1326

\section{Comments in the Internet Media as the Reflection of National Mentality Peculiarities}

\author{
Liliya R. Abdullina' ${ }^{1}$ Liliya R. Nizamieva², Gulnara I. Nazarova³
}

\begin{abstract}
The article is devoted to defining the peculiarities of national perception through the analysis of the comments taken from news media. The research is based on comparative and contrastive analysis of the reader's comments to the articles devoted to the terroristic attack in Nice happened on July 14, 2016 and reflected in mass media in the French and Russian languages. On the first stage of the research the object of comment and the peculiarities of its representation in two languages are defined. On the second stage of the research the frame analysis of the studied material is fulfilled, consisting of defining the contextual frames. The key topical subframes, which in turn are divided into slots, are determined in the structure of frames. The logical-semantic relations are built among the structural elements of frames. The possibility of crossing topically-different subframes within one frame is demonstrated. The frequency of domination of this or that slot in comments is defined and explained. The allomorphic and isomorphic features defined in the research show the peculiarities of cultural and historical values influencing national mentality.
\end{abstract}

Keywords: Internet-comment, Virtual discourse, World perception, Logical-semantic relations, Frame, Subframe.

\footnotetext{
${ }^{1}$ Kazan Federal University, E-mail: lilioven@mail.ru

${ }^{2}$ Kazan Federal University.

${ }^{3}$ Kazan Federal University.
} 


\section{Introduction}

In recent decades the attention of the researchers in linguistics is concentrated on language peculiarities of different genres of Internet discourse, among which the following ones are dominant: chats, blogs, and forums (Orimaye et al., 2013; Cercel \& Trausan-Matu, 2014; Ascone, 2015). Recently the works based on the analysis of Internet comments which are increasingly popular in the news lines of different sites have appeared. Some authors devote their researches to the analysis of the microstructure of conversation and the coherence of dialogue established by cooperation of participants in Internet-comments (Hennoste et al., 2010), others study evaluative modality (Karpoyan, 2011; Koit, 2015). Some linguists single out Internet comments to news articles as a separate speech genre of Internet discourse (Saveliyeva, 2013; Abdullina et al., 2014). This research is the first attempt of the comparative analysis of comments to news articles as a genre of Internet discourse in the languages having different structure due to the pragmaticsemantic paradigm. The aim of the analysis is to define the national and cultural peculiarity in perception of the recent events represented through the language means in the Internet comments. The hypothesis of the research is based on the statement that the comments in the Internet media are able to reflect national peculiarities of the culture and history of native speakers and their habitat. We also take into consideration the peculiarities of person's self-awareness which is 'determined by ethnic, confessional and historical determinants' (Mukhametshina \& Galimullina, 2014).

\section{Material and Methods}

The research is based on the methods of frame modeling and comparative-parametric. The method of frame modeling allows to define contextual frames (Fillmore et al., 2003; Bayer \& Riccardi, 2016), which make up the core of the frame structure and later may be subdivided into subframes - the layers which represent a set of thematically common features and are the chains of slots placed in hierarchical order (Guselnikova, 2010).

The main idea of the comparative-parametric method is to use formalized parameters in description of national peculiarity of the languages, according to certain defined aspects (Sternina, 2015). The characteristic of this or that language or cognitive feature within a certain parameter is shown in the form of an index measured in percentage. We define the index of inter-frame logical-semantic relation of frame - the relation of the number of lexemes, which are included into structural elements of the frame by different sememes, to the total number of lexemes of this frame.

The Internet comments to the articles devoted to the terroristic attack in Nice on July 14, 2016, the event which raised a great public reaction in the world, were used as the material for the research. They were taken from the leading online newspapers in the French language ('Le Monde', 'Liberation') and the Russian language ('Gazeta', 'Moskovsky Komsomolets').

\section{Results}

We turn to the frame analysis of the material which has close connection with the objects of the comments described above. The frame of the comments corresponds with the topic of the article. The difference is shown on the level of subframes. In the comments in both languages we define subframe 'Politics'. The slots which fill these subframes are also practically identical, except for the presence of numerous comments in the French language, which are devoted to the mayor of Nice. This can be proved in the following example:

In French: Il faudra tout de même que monsieur Estrosi Maire de Nice nous explique comment un soir de fête nationale, alors que la promenade des anglais est noire de monde, une semi-remorque puisse y 
accéder sans même à avoir à franchir un barrage de police ou renverser la moindre barrière de sécurité, alors que la simple pose d'une herse aurait suffit à éviter le drame. Gouverner c'est prévoir monsieur le Maire.

In the Russian comments the name of Christian Estrosi was not registered. However, the most remarkable person in the world politics - the then President of France Hollande - is in the center of attention in the French and Russian comments. It should be noted that both nations express negative attitude towards his policy. For example:

In French: Hollande qui a échoué dans tous les domaines: chômage, CGT, sécurité prospérité... doit démissionner.

In Russian: Французские силы правопорядка явно неуд. Оланд-явно неуд. Да здравствует свободная Франция без социализма! (The French police forces - unsatisfactory. Hollande unsatisfactory. Long live free France without socialism!)

Together with blaming the political activity of the president, the political activity in general is being commented: in the Russian language the comments are characterized by blaming politicians in general, in the French language - a certain political parties.

In French: En résumé, l'extrême-droite est clairvoyante sauf quand elle ne l'est pas.

In Russian: Жалко людей, они платят за ошибки политиков. (We feel sorry for people, they pay for the mistakes of the politicians)

This allomorphism demonstrates the involvement of the citizens into the political life of the country which is defined by the political awareness based on the knowledge about the politics. It is logical that more comprehensive expertise about the politics of France, particularly about its political parties and leaders, allow the French to discuss the topic of activity and inactivity of the parties, making comparisons and assessing their behavior. The slot 'Political parties' is specific to the slot 'Politicians'. Correspondingly, in case of absence of enough knowledge in the sphere, foreign commentators use logical generalization.

At present the activity of the Russian media is directed to the countering actions towards the ideology of the terrorism (subframe 'Terrorism'), influencing the Russians suggestively. The comments of the native speakers clearly demonstrate the difference in attitudes towards the Islam religion. There are regions in Russia where the lives of the representatives of different religions, including Christians and Muslims, are built on respect and tolerance. For example, the Republic of Tatarstan, most of the population of which is comprised by Tatars, who are Muslims (53.2\%), 'the second largest nationality are the Russians (39.7\%)' (Nizamieva et al., 2016). It is the reason why the opinions towards Islam are neutral.

In Russian: С исламским терроризмом может покончить только и исключительно исламский мир. (Only and exclusively Muslim world can stop Islam terrorism.).

The attitude of the French towards Muslims is not separated from the problem of immigration, because the great number of foreigners comes to France from the countries where the state religion is Islam which they try to integrate into the French society. The increasing number of people of non-French culture led to rethink the constituent elements of the French identity and unhidden racism. That is why the comments of the French are full of opinions towards migrants who follow Islam and constantly organize terroristic attacks in the country instead of law-abiding behavior in the country of their new home.

In French: Si on intègre sur une longue période, c'est quand même la droite qui a fait venir le plus d'immigrés (le Japon avec population 2 dois plus importante que la France a 2 fois moins de travailleurs immigrés). Ils ont des robots, on a des terroristes. 
In such cases we observe logical relations of crossing between the slots 'Muslims' and 'Migrants', the volumes of which partially correspond: a certain group of migrants in France can be Muslims and, in the opposite, there can be Muslims among migrants.

Within the subframe 'Terrorism' there are three more slots in the Russian comments, which are not registered in the French language. The first slot is devoted to ISIL:

Под самым носом у французских спецслужб вербовщики иГиЛ творят, ито хотят. (Under the French intelligence organization's very nose, ISIL do what they want.)

The second slot touches the topic of NATO:

А где-же блок НATO???? Черт подери...забыл... они же на Балтике плацдарм готовят...против Poccuu. (And where is NATO???? Damn it... forgot... They are preparing a base area at the Baltic region... against Russia.)

The irony of the Russian author towards the actions of NATO is clear: except for providing peace and safety in the European countries, NATO is preparing for the war with Russia, because this is the way how the actions of NATO are interpreted in all Russian media due to the anti-Russian policy of many foreign states because of the Russian-Ukrainian conflict.

And the third slot is 'Charlie'.

Горе конечно, но ... помните как "Шарли эбдо" отреагировало на теракт нашего самолета в Египте???...вот теперь эта поганая газетенка пусть посмеется над своими соотечественниками.... (It is a misfortune, of course, but...do you remember how 'Charlie Hebdo' reacted on the terroristic attack with our plane from Egypt???...so now this damned newspaper will laugh at their compatriots...

The existence of such kind of aggressive comments towards Charlie proves that the published caricatures of the Russian plane crash in $\mathbf{2 0 1 5}$ are not forgotten. These caricatures were seriously criticized by the Russian government. The Russians assessed the caricatures on the topic of the tragedy which took 224 lives as the sacrilege and called them antihuman. Despite the fact that the French themselves do not share the point of view of this satire issue, the incident had a negative effect on France with the help of mass media. Since that time for some Russians, the French seem to be indifferent to the grief of other people and devoid of tolerance; the memories are still in their minds.

The subframe 'France' is registered in both languages. France is a specific notion of the slot 'the West'. The relations of implication between these notions determine mentioning of the country as a part of Europe, the West. Moreover, the subframe 'France' includes the slot 'Russia' in the Russian comments. From the logical-semantic point of view, two notions within the contextual frame are in opposition which explains a plenty of comparisons and contrasts between France, or Europe as a whole, and Russia (13\%).

In Russian: Cтрах и горе накроют Европу, если европейские политики не обдумаются и не объединятся с Pоссией. (Fear and grief will cover Europe if European politicians do not think it over and unite with Russia)

The interest to the French-Russian cooperation is especially modern for the Russians because of worsening the relations between the West and Russia due to the events in the Ukraine. The sanctions spoilt the diplomatic work on mutual understanding and cooperation. The difficulties of the country made the patriotic spirit of the Russians stronger.

It should be mentioned that the subframe 'France' can cross within the contextual discourse either with the subframe 'Politics' or the subframe 'Terrorism', or both simultaneously. Study the following example; 
In French: Pourquoi Hollande s'entête dans ses interventions a minima en Syrie et en Irak, alors que nos moyens de protection contre les réactions de ces fous sont si faible en France?

So, 'Hollande', 'Власти' (authorities) belong to the subframe 'Politics', the word 'France' belongs to the subframe 'France', 'en Syrie et en Irak' / 'террористической угрозы' (terroristic threat) belong to the subframe 'Terrorism'.

\section{Discussion}

The main difference is observed in quantitative relation of the representation of the subframe 'Politics' in two languages. In the French language $57 \%$ of the comments touch the topic of politics, in comparison with Russian $33 \%$. So, the French are really worried by the political problems of the country that supposes the high level of civil engagement. Moreover, the mentality of the modern French which was formed to a certain extent by the Revolution of 1789, transforming not only the social and economic structure of the country, but the psychology of the nation as well, and now defines their criticism towards the government. In Russia, in the opposite, the French Revolution made the government strengthen the legal basis of state censure, limiting the freedom of word and opinion towards the politics and politicians. These historical factors explain the indifference of the Russians towards the politics: according to the results of the social surveys of the recent years, only $30 \%$ of the population express worries connected with political issues.

The dominant subframe in the Russian comments is terrorism (73\%), in contrary to the French (49\%). The common features are observed in the filling of subframe with such slots as 'Terroristic attack', 'Muslims' and 'Middle East'. The isomorphism is defined in the presence of the slot 'Middle East', which is connected with the participation of the West in the war in this region, in the structure of the subframe 'Terrorism' in both languages. From the logical-semantic position the slots 'the West' and 'Middle East' are in contrary relations within this discourse: they refer to the same kinds 'Part of the world', but the West has the features that are strange to the countries of the Middle East and represent, in certain comments, chaos, which often creates terrorism.

The subframe 'France' is printed in both languages in equal parts (In French - 49\%, in Russian - 55\%).

\section{Summary}

The analysis of the material helped to define common and specific features of the perception of the terroristic attack happened in Nice by the readers who belong to different nationalities. In both languages there are three common semantically-connected subframes. The comparison of the indices of interframe logical-semantic connection of the subframes showed that the subframe 'Politics' occupies the dominant position in the French comments, whereas the subframe 'Terrorism' is dominant in the Russian comments. The allomorphism is detected in the structure of the defined subframes, especially, those which make up their slots.

\section{Conclusion}

As the analysis of the material showed, the comments to the news media demonstrate national peculiarity in the perception of the world formed under the influence of some historical events such as the French bourgeois revolution of 1789 in France and social-economic and public-political terms of nation's life. The cultural and historical values of this or that country impact the verbal reflection of reality, based on the determination of the subjective priorities through the hierarchy of the meanings of 
the images, the correlation of the past experience of the human and their environment with the objects of reality, the determination of behavior and activity of the subject as a part of communicative act.

\section{Acknowledgements}

The research is performed according to the Russian Government Program of Competitive Growth of Kazan Federal University.

\section{References}

Abdullina, L. R.; Ageeva, A. V. \& Smirnova, E. A. (2014). "The Evolution of the 'Comment' Genre: Theoretical Aspect." World Applied Sciences Journal, 29(3), 354-358.

Ascone, L. (2015). "The computer-mediated expression of surprise: A corpus analysis of chats by English and Italian native speakers and Italian learners of English." Review of Cognitive Linguistics, 13(2), 383-414.

Bayer, A. O. \& Riccardi, G. (2016). "Semantic language models with deep neural networks". Computer Speech and Language, 40(1), 1-22.

Cercel, D. C. \& Trausan-Matu, S. (2014). "Opinion influence analysis in online forum threads." Proceedings in 16th International Symposium on Symbolic and Numeric Algorithms for Scientific Computing (SYNASC), pp. 228-235.

Fillmore, C. J.; Johnson, C. R. \& Petruck, M. R. (2003). "Background to Framenet." International Journal of Lexicography, 16(3), 235-250.

Guselnikova, O. V. (2010). "Terminologicheskiy apparat strukturyi freyma (Frame structure terminology)." Journal of Chelyabinsk State pedagogical university, 9, 137-149.

Hennoste, T.; Gerassimenko, O. G.; Kasterpalu, R.; Koit, M.; Laanesoo, K.; Oja, A.; Rääbis, A. \& Strandson, K. (2010). "The structure of a discontinuous dialogue formed by internet comments." Lecture Notes in Computer Science, (pp. 515-522). Brno: Springer.

Karpoyan, S. M. (2011). "Otritsatelnyie modalnyie otsenki v internet-kommentarii (Negative Assessment in Internet-Commentary Scientific)." Thought of Caucasus, 3(67), 115-119.

Koit, M. (2015). "Debate formed by internet comments." Towards the automatic analysis. IC3K 2015 Proceedings of the 7th International Joint Conference on Knowledge Discovery, Knowledge Engineering and Knowledge Management, 2, 328-333.

Koshel, P. V. (2013). "Frantsuzskiy internet-kommentariy kak rechevoy zhanr (French online comment as a speech genre)." Journal of Moscow State linguistic university, 10(670), 80-89.

Laineste, L. (2013). “Funny or aggressive? failed humour in internet comments." Folklore, 53, 29-46.

Mukhametshina, R. F. \& Galimullina, A. F. (2014). "Inculcation of Bimental personality in context of cultural dialogue." Middle-East Journal of Scientific Research, 20(12), 2135-2138.

Nizamieva, L. R.; Nazarova, G. I. \& Ostroumova, O. F. (2016). "Teaching French as a Foreign Language in the Multilingual Environment (The Example of Tatarstan Republic)." The Social Sciences, 11(6), 1035-1041. 
Orimaye, S. O.; Alhashmi, S. M. \& Siew, E. G. (2013). “Can predicate-argument structures be used for contextual opinion retrieval from blogs?" World Wide Web, 16(5-6), 763-791.

Savelyeva, I. V. (2013). "K voprosu o zhanrovyih priznakah internet-kommentariya (On the genre features of online comments)." Genres and types of text in the scientific and mass-media discourse, 11, 194-202.

Sternina, M. A. (2015). "Sopostavitelno-parametricheskiy metod lingvisticheskih issledovaniy: pervyie itogi (Comparative-parametric method of linguistic research: first results)." Journal of Voronezh State University, 3, 92-94. 